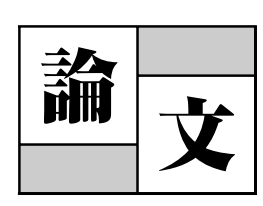

\title{
エレクトロスピニングに扔ける紡糸条件と変形挙動の関係
}

\author{
角 前 洋 $介^{* 1} \cdot$ 杉 本 昌 隆 ${ }^{* 1} \cdot$ 谷口貴 志*1,2 小山清 人*1
}

\section{Relation between Spinning Conditions and Jet Profile in Electrospinning}

\begin{abstract}
Kadomae, Yosuke*1/Sugimoto, Masataka*1/Taniguchi, Takashi ${ }^{* 1,2} /$ Koyama, Kiyohito $^{* 1}$
Relationship between electrospun fibers and spinning conditions are investigated from the view point of jet profiles such as diameter distribution, jet velocity, and the evaporation rate of solvent from the surface of jet in solution electrospinning process by changing (i) the applied voltage and (ii) the relative humidity of ambient air. Profiles of jets near the droplet at the tip of needle are measured as functions of the position along the spinning line by using photographs. The measured profiles of jet can be fitted nicely by the analytic expression of spinning profile for a nonevaporating Newtonian fluid, which enables us to calculate the velocity profile of jets and the evaporation rate of solvent from the jet as a function of the position along the spinning line. Changing the applied voltage, it is found that the jet velocity and the evaporation rate in our measured region are decreased and beaded fibers are increased when increasing the applied voltage, on the other hand the total amount of evaporated solvent from a jet in our measured region is too small to affect the profile of jet and to change the viscosity of solution in the jet. Changing the relative humidity, it is found that profiles of jets are almost the same except for the evaporation rate. The evaporation rate in our measured region is increased by decreasing the relative humidity. In the lower humidity region, less than $60 \%$ of humidity, beaded fibers are hardly formed, but in the higher humidity region, more than $60 \%$, beaded fibers are increased with increasing humidity. From the results in two conditions (i) and (ii), it is found that the beaded fibers are easily formed as the evaporation rate of solvent becomes smaller.
\end{abstract}

Key words : Electrospinning/Spinning condition/Nano-fiber/Jet profile/Evaporation rate

\section{1. 緒言}

エレクトロスピニングは, 高分子溶液, 又は高分子溶融 体に高電圧を印加することによって, 超極細繊維による繊 維構造体を作製する技術である。この技術によって作製さ れる繊維は, 通常の紡糸法である溶融紡糸や溶液紡糸に比 べて非常に細い繊維径と, 大きな比表面積を持つ。これら の特性は, 超高性能フィルターから人工蔵器 (血管や尿管)

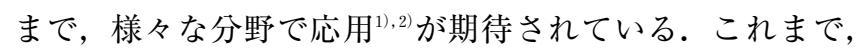
多くの研究者たちによってエレクトロスピニングにおける

\footnotetext{
*1 山形大学大学院理工学研究科

Graduate School of Science and Engineering, Yamagata University

米沢市城南 4-3-16（勇992-8510）

4-3-16 Jonan, Yonezawa 992-8510, Japan

*2 JST, CREST

2008.10.8 受理
}

様々な条件について, 実験的, 理論的に研究がなされ, 試 料条件 (分子量 ${ }^{3) ~ 5)}$ や溶液濃度 $^{(6)}$, 表面張力 ${ }^{7,9)}$, 導電率 ${ }^{7), 10)}$, 分子構造 ${ }^{8}$, 分子量分布 ${ }^{5}$ など) と紡糸条件 (極板間距離 $\left.\left.{ }^{6}\right), 11\right)$ や印加電圧 ${ }^{6), 12)}$, 湿度や雲囲気ガスなどの紡糸環境(6),13), 試 料の吐出流量 ${ }^{6,10)}$, ニードル 径 $\left.{ }^{14)}\right)$ などが重要なパラメー タであることがわかっている.エレクトロスピニングでは, ビーズと呼ばれる球状の物体がしばしば発生し, ビーズの 発生によって繊維構造体の物性が変化することも報告され ている ${ }^{15)}$ 。このビーズ発生を制御することにより製品物性 の制御が可能となることが期待されるが, 特に繊維径を細 くしたい場合のビーズ抑制法については詳しく分かってい ない. 今までの研究によって, 低い表面張力や高い溶液濃 度・高分子量化によりビーズ発生が抑制できることが分 かっている7 が，いずれの方法も繊維径が太くなるという 問題点がある．紡系条件に着目した場合，印加電圧や湿度 を変化させることで, 繊維径やビーズ発生の制御ができる

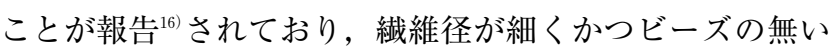


纎維を作製した例もある。このように, 紡糸条件の相違に よって繊維構造が異なるということは, 紡糸中の変形挙動 が紡糸条件によって変化していることが考えられる．しか し, 紡糸条件を変化させたときの紡糸中の変形挙動は, はっ きりと分かっておらず，特に溶媒の揮発速度変化は我々の 知る限り報告されていない，溶液を用いたエレクトロスピ ニングの場合, 試料は変形を受けると同時に溶媒が揮発し ており, 変形速度の変化に伴って揮発速度も刻々と変化し ていることが予想される. よって, 揮発速度の変化や吐出 口から任意の位置までの揮発量を見積もることは得られる 纎維の繊維径や繊維構造の違いを理解するために非常に重 要であると考えられる.

そこで, 本研究では, 紡糸条件（印加電圧と湿度）を変 化させたときの変形挙動や揮発速度変化, 揮発量について 調べることを目的とした。

\section{2. 実験方法}

試料として用いる溶液には，蒸気圧の計算が容易になる ように，溶媒に水を用い，溶質に水溶性高分子であるポリ ビニールアルコール（PVA）を用いた。本実験で用いる 溶液濃度を選択するために幾つかの濃度で予備実験を行い, 紡糸条件によって繊維構造が変化しやすい濃度であった $15 \mathrm{wt} \%$ を選択した。エレクトロスピニングの装置概略図 を図 1 に示す.作製したPVA 水溶液をシリンジに充填し, 試料を内径 $500 \mu \mathrm{m}$ のニードルからシリンジポンプによっ て一定吐出量 $Q_{0}=0.2 \mathrm{ml} / \mathrm{hr}$ で押し出し, 高圧電源によっ てニードルに高電圧を印加することで試料を帯電させた。

接地した収集板をニードル先端から $10 \mathrm{~cm}$ の位置に置き， 収集板上に液滴が付着しないように水平方向に紡糸を行っ た. 紡糸環境の相対湿度は乾燥空気と湿潤空気とを混合す ることによって制御した。今回調査した紡系条件は（1）印 加電圧と（2）相対湿度である. 印加電圧の影響の調査で は，相対湿度を最も制御し易く安定している $50 \%$ に設定 し, $9 \mathrm{kV}, 12 \mathrm{kV}, 18 \mathrm{kV}, 24 \mathrm{kV}$ の 4 つの印加電圧条件 で実験を行った. 相対湿度の影響の調査では, 繊維状の構 造が最も得られ易かった印加電圧である $9 \mathrm{kV}$ に固定し, 相対湿度を $20 \%$ から $70 \%$ まで $10 \%$ ずつ変化させて実験 を行った. 紡糸中の変形挙動を観察するために, 図 1 に示 すように光源と CCD カメラを正対するように設置した. 電圧印加によって射出されるジェットはしばらく直進した 後, 不安定領域に突入し回転運動を行う。回転運動が加わ る前後では，ジェットが奥行き方向にも運動するため，力 メラの焦点から外れて鮮鋭な画像が撮影できなかった。そ のため，比較的焦点を合わせやすいニードル先端付近での 試料の変形を CCD カメラで撮影した. 印加電圧を変化さ せたときのニードル先端付近での試料の典型的な変形を 図 2 (a)に示す。得られた画像から図 2 (b) に示すように, 紡糸線方向（ジェットの射出方向）に $x$ 軸を取り， $x$ 軸に 垂直方向の試料直径をおよそ $4 \mu \mathrm{m}$ 間隔で計測した. 試料 が細化する要因は, 試料の流速の増加と溶媒の揮発による 糸の体積の減少とが考えられる. そのため, 画像から得ら れた直径分布に揮発の影響があるかどうかを明確にする必 要がある. そこで, 試料がニュートン流体でかつ, 試料の 粘度が紡糸線上で変化しないと仮定したときに理論的に求

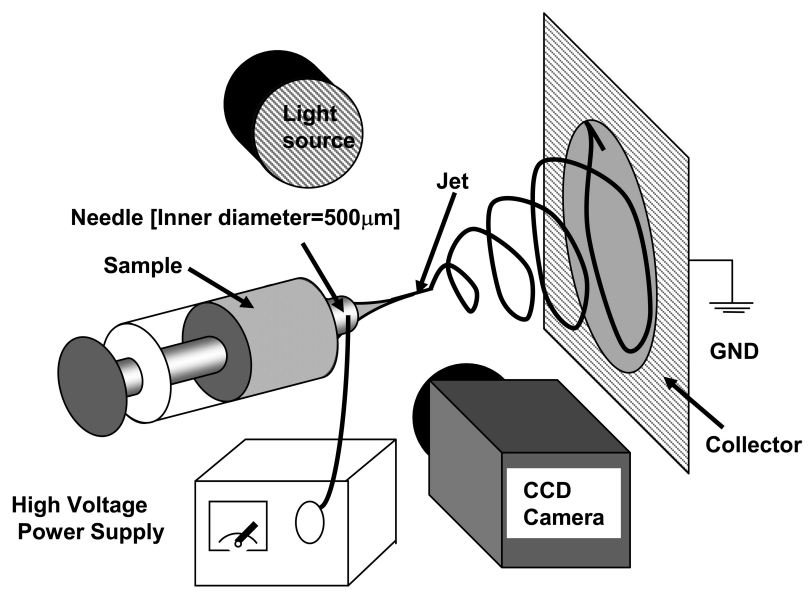

Fig. 1 Scheme of the electrospinning setup.

(a)

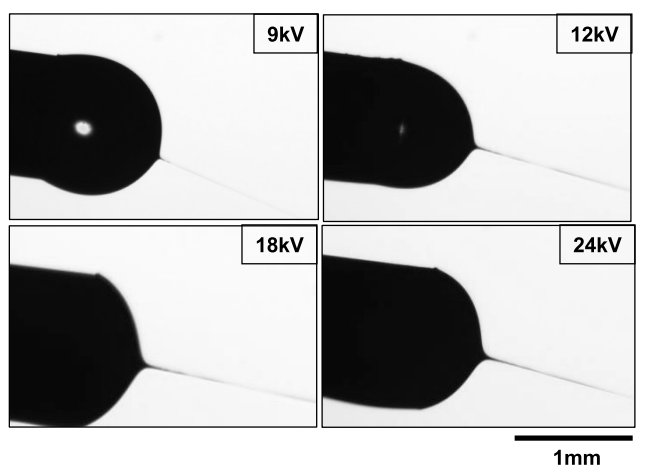

(b)

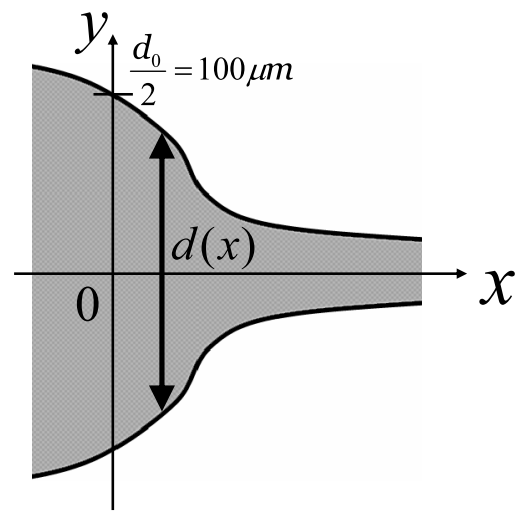

Fig. 2 (a) Photographs of Taylor cone and jet in electrospinning processes at different voltages, 9 $\mathrm{kV}, 12 \mathrm{kV}, 18 \mathrm{kV}$ and $24 \mathrm{kV}$.

(b) Illustration of jet in an electrospinning process.

められる紡系の直径分布と, 実験により撮影した画像を用 いて測定した直径分布とを比較し，揮発が紡糸形状に与え る影響を調べた。試料が揮発のないニュートン流体と仮定 したときの紡糸の直径分布 $d_{N}(x)[\mathrm{m}]$ は次式(1)によって 与えられる。

$$
d_{N}(x)=d_{N 0}\left(\frac{v_{w}}{v_{0}}\right)^{-\frac{x}{2 L}}
$$

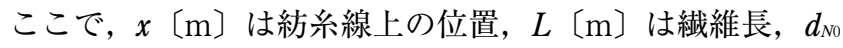
〔m〕はジェットの初期直径， $v_{0} 〔 \mathrm{~m} / \mathrm{s} 〕$ は初期速度， $v_{w} \llbracket \mathrm{m}$ 
(a)
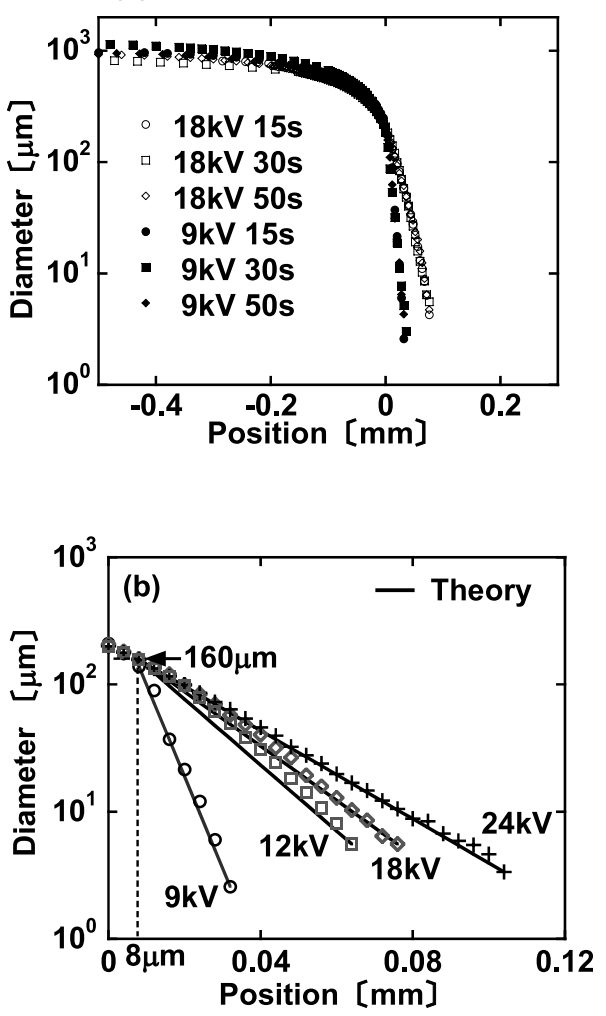

Fig. 3 (a) Time dependence of jet diameter profiles on each time after initiation of electrospinning, $15 \mathrm{~s}, 30 \mathrm{~s}$ and $50 \mathrm{~s}$ at different voltages, $9 \mathrm{kV}$ and $18 \mathrm{kV}$.

(b) Comparison of measured jet diameter profiles and calculated jet diameter profiles of a non-evaporating Newtonian fluid at different voltages, $9 \mathrm{kV}, 12 \mathrm{kV}, 18 \mathrm{kV}$ and $24 \mathrm{kV}$.

/s]は $x=L$ の位置での速度である. 図 $3(\mathrm{a})$ に $9 \mathrm{kV}$ と 18 $\mathrm{kV}$ で紡糸を行った際の紡糸開始から 15 秒，30 秒，50 秒 経過したそれぞれの時間に観察された直径分布を示す．基 準点 $(x=0)$ まではばらつきがあるが，基準点以降の直径 分布はそれぞれの電圧でほぼ一致することが分かる。この ことから，紡糸が行われているときはジェット直径が時間 に依存しないとして解析を行った。式(1)によって求めた 紡糸の直径分布と今回の観察範囲内での直径分布を図 3 (b)に示す．図 3(b) から分かるように，実験結果と式(1) の直径分布はほとんど一致することが分かる．このことか ら, 今回の観察可能であった範囲では, 揮発の紡系形状へ の影響がほとんど無い，つまり，揮発量が糸の体積に比べ て十分小さいと結論づけることができる，そこで，紡糸線 に垂直な任意の断面を単位時間当たりに通過する流量が一 定とし, 位置 $x$ でのジェットの速度 $v(x) 〔 \mathrm{~m} / \mathrm{s}$ を次式 (2) によって算出した。

$$
v(x)=\frac{4 Q}{\pi[d(x)]^{2}}
$$

ここで $\left.Q 〔 \mathrm{~m}^{3} / \mathrm{s}\right\rceil$ は溶液の流量, $d(x)[\mathrm{m}]$ は位置 $x$ での ジェットの直径である. 後で示す揮発速度 $w$ (式 (4)) と 液滴の形状から求まるおおよその表面積から, 液滴の体積 と同量だけ紡糸するのに要する時間内に液滴表面から揮発
する水の量と液滴の体積の比 $\xi$ は,

$$
\xi=\frac{4 \pi r^{2} w}{Q_{0}}
$$

で表わされる。ここで， $r$ は液滴を球と見立てた時のおお よその半径， $Q_{0}$ はシリンジポンプから押し出される溶液 の吐出量である. 実験值から $\xi$ を見積もると, $\xi \cong 2 \times 10^{-4}$ と極めて微小であった. 吐出量は電圧や時間とともに変化 することが予測されるが，実験中の吐出量を求めることが 困難であり，今回は求めることが出来なかった。そこで, 式(2)の溶液の流量 $Q$ にはシリンジポンプによって押し出 される溶液の吐出量 $Q_{0}$ を用いた.

今回の測定結果とは別に，過去にトレーサー粒子を用い て測定した速度と (2) 式で算出した速度が比較されており, そこでも両者がほぼ一致することが報告 ${ }^{17)}$ されている。

溶液からの溶媒の揮発速度は，溶液表面とそれを取り巻 く気体との相対速度に依存することが知られている. 実際, 水の揮発速度 $w\left\lceil\mathrm{~g} / \mathrm{m}^{2} \cdot \mathrm{s} 〕\right.$ は取り巻く空気の風速が $0.5 \mathrm{~m} / \mathrm{s}$ 程度までは風速にほとんど依存せず，それ以上の 風速になると風速の大きさに比例し ${ }^{18)}$, 次式 (4)で与えら れることが分かっている。

$$
\begin{aligned}
& w=K\left(p_{s}-p\right)(v<0.5 \mathrm{~m} / \mathrm{s}) \\
& w=C v\left(p_{s}-p\right)(v \geq 0.5 \mathrm{~m} / \mathrm{s})
\end{aligned}
$$

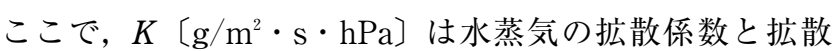
層の有効厚さから求まる定数で, $C\left\lceil\mathrm{~g} / \mathrm{m}^{3} \cdot \mathrm{hPa} 〕\right.$ は水蒸 気の拡散係数と空気の動粘度の比によって求まる定数であ

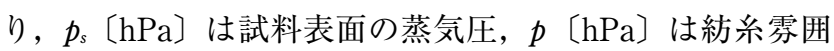
気の蒸気圧である. 今回の系では, 紡糸雲囲気である空気 の中をジェットが自由表面を持って飛んでいくため, ジェットの速度を風速に置き換えることができる．以上か ら, 紡糸線上の位置 $x$ での揮発速度 $J_{e}(x)$ を式(2)により 算出したジェットの局所速度と式(4)を用いて算出した。 この算出において, 試料表面の蒸気圧 $p_{s}$ は測定した試料 温度での飽和蒸気圧を用いて，また，紡糸雲囲気の蒸気圧 $p$ は，紡糸雲囲気の相対湿度から求めた。

実験後得られた繊維は走査型電子顕微鏡（SEM）を用 いて纎維構造を確認し, SEM 画像から画像解析ソフトを 用いて繊維径分布を求めた。 ビーズが発生した場合はビー ズの部分を除外し, 繊維部分のみを繊維径として計測した。

\section{3. 実験結果と考察}

\section{1 印加電圧の影響}

印加電圧を変化させたときのニードル先端でのコーン形 状を図 2 (a)に示す. $9 \mathrm{kV}$ の場合は, 他の電圧の場合に比 ベてコーン先端から射出されたジェットが細いことが確認 できる．また，電圧によってニードル先端からコーン先端 までの長さが異なる，エレクトロスピニングでは，液体表 面にある電荷間の静電反発力が表面張力よりも勝りジェッ トが射出されるので，コーン先端近傍までの挙動は繊維構 造や繊維径に無関係であると考えられる。そこで，コーン 先端での変形挙動の違いを分かりやすくするために, 直径 分布の基準点 $(x=0)$ をニードル先端ではなく, 直径 $d$ が $200 \mu \mathrm{m}$ になる点に置いて解析した (図 2 (b) 参照). 図 3 
（b）は，各電圧における直径分布と理論式を用いてフィッ トした結果を示している. 図 $3(\mathrm{~b})$ から分かるように各電 圧での直径分布に対してフィットした理論線はほぼ同じ座 標で交差し，その座標 $\left(x, d_{N 0}\right)$ はおよそ $(8 \mu \mathrm{m}, 160 \mu \mathrm{m})$ であった：ニュートン流体の紡糸と仮定しての理論線であ ることから, 直径の変化が式 $(1)$ と合う始めの点 $(x=8 \mu \mathrm{m})$ が紡系開始点と考えられる. ジェットが不安定化する領域 は今回の観察範囲からさらに遠い, $x=1 \sim 2 \mathrm{~mm}$ 程度から 始まると思われる。（1)式で用いた $L$ は直径が測定可能で あった最後の $x$ の值を用いている. また，一般的にコーン からジェットが射出される過程において, 直径変化の傾き はコーンからジェット射出までとジェット射出後の 2 段階 に変化することが知られている ${ }^{177}$ が, 今回の測定結果では ほとんどの条件において 2 段階の変化を示さなかった。こ の理由は撮影の倍率が低く, 分解能が低かったことによる と考えている.これらのことから，コーンからジェットが 射出されるまでの領域（今回の測定では $x=0$ から 30〜 $120 \mu \mathrm{m}$ まで） がニュートン流体とみなせると考えられる. $9 \mathrm{kV}$ で紡糸した時は他のより高い電圧で紡糸した時より も急激に直径が減少していることがわかる. $12 \mathrm{kV} て ゙$ 紡糸 した時は $9 \mathrm{kV}$ で紡系した時と比較して直径の減少は緩や かになり，さらに電圧が $18 \mathrm{kV}, 24 \mathrm{kV}$ と高くなるにつれ て直径変化が緩やかになっていくことがわかった．この直 径分布の測定結果を基に算出したジェットの速度分布を 図 4 に示す. 図 4 中の実線はニュートン流体と仮定した時 の速度分布であり, 各電圧における速度分布は実線で示し た速度分布とそれぞれ一致していることが分かる．直径の 減少が著しかった $9 \mathrm{kV}$ では, ジェットの速度分布でも同 様に，他の電圧で紡糸した場合よりも急激な速度の上昇が 確認できる. $12 \mathrm{kV}$ 以上で紡糸した時も同様に, 直径の変 化が緩やかになった分, 速度変化も緩やかになっている.

$12 \mathrm{kV}$ 以上の電圧で紡糸した際，コロナ放電特有のスナッ プ音やオゾン臭を確認している.このことから, 電圧の上 昇と共に放電が起き, 放電によって紡系空間中に電荷が存 在し，この電荷がジェットの変形を緩やかにしたと考えら れる. 実際，放電流を測定し放電の開始電圧を確認したと ころ, $10 \mathrm{kV}$ 程度から放電流が指数関数的に大きく上昇す ることを確認した。 また，各電圧におけるドラフト比 $\left(v_{w}\right.$ $\left./ v_{0}\right)$ は, 印加電圧の増加とともに減少する傾向にあった. 次に, 得られた速度分布より算出した揮発速度分布を図 5 に示す. $9 \mathrm{kV}$ で紡糸した時は急激な速度上昇を示すため, 揮発速度も早い位置で上昇し始めることが分かる. $12 \mathrm{kV}$ 以上の電圧で紡糸した際は，電圧上昇に伴って揮発速度の 上昇する位置が $9 \mathrm{kV}$ の時と比べて下流側になる。このよ うな電圧が高くなるにつれて変形速度・揮発速度が変化し ていく傾向はさらに高い濃度（粘度）の試料でも同様とな ることを確認している.ここで, 各電圧で紡糸した際の繊 維構造と繊維径分布を図 6 と図 7 に示す. $9 \mathrm{kV}$ の時は均 一な繊維構造が観察されたが, それ以外の電圧ではビーズ 構造が観察された. 加えて, 䋊維径分布は電圧の増加とと もに若干広くなり, 平均繊維径も僅かに増加した。これら の結果は過去に報告 ${ }^{19)}$,20)されている傾向と一致している. このことからも, 電圧が高くなるにつれて放電が発生し, 試料の伸長変形が抑制されることが考えられる. 今回得ら

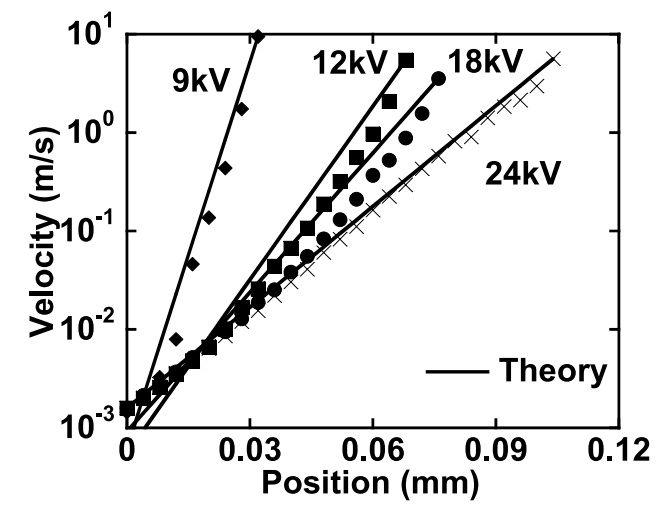

Fig. 4 Comparison of jet velocity profiles calculated from jet diameter profiles and calculated jet velocity profiles of a non-evaporating Newtonian fluid at different voltages, $9 \mathrm{kV}, 12 \mathrm{kV}, 18$ $\mathrm{kV}$ and $24 \mathrm{kV}$.

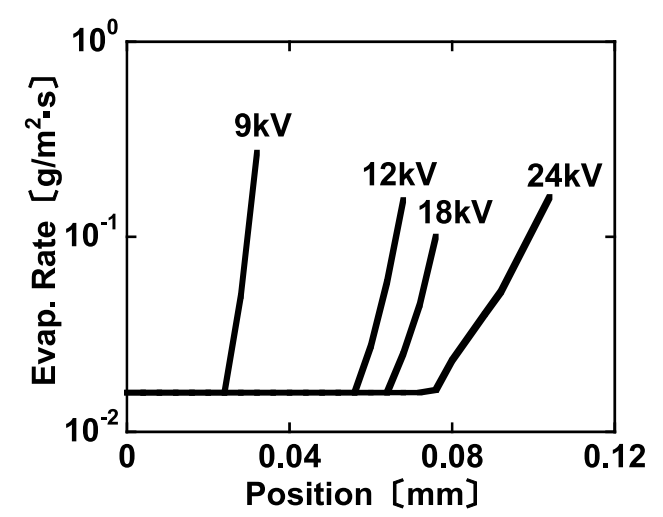

Fig. 5 Evaporation rate calculated from jet velocity as a function of the position $x$ for different voltages, $9 \mathrm{kV}, 12 \mathrm{kV}, 18 \mathrm{kV}$ and $24 \mathrm{kV}$.

れたジェットの速度分布と直径分布から, 各点間の所要時 間, 表面積を求め, 揮発速度分布を基に, 溶媒の揮発量を 算出した. その後, 初期の高分子濃度と得られた揮発量か ら溶液濃度の変化を見積もると，濃度変化は $0.005 \mathrm{wt} \%$ 程度と極めて微小な変化であった。つまり, 今回の観察範 囲では揮発がほとんど起きていないことが分かる。しかし， 揮発速度は径が細くなり紡糸線上の速度が速くなることで, さらに上昇していくことが考えられ，単位体積あたりの表 面積も径の細化に伴い著しく上昇をすることを考えると， 観察範囲より先の下流側での現象を予測する上で, 今回の 結果は十分に意味のあるものである.

以上の結果をもとに，観察範囲よりも下流側の変形挙動 を推測した. 今回観察可能であった範囲ではまだ固化は生 じないが， $9 \mathrm{kV}$ で紡糸した時が一番速く溶媒の揮発が進 み，下流側での最終的な固化が早いことが考えられる。一 方 $12 \mathrm{kV}$ 以上の電圧では, 電圧が高くなるにつれて固化 が遅くなることが考えられる. さらに, 揮発速度が速いと 溶媒の揮発に伴う溶液濃度上昇, 即ち粘度上昇につながり, 揮発速度が遅い場合はその逆の傾向になる．本論文中では， いずれの場合も観察可能であった範囲では揮発量が十分で はないので粘度の上昇はないが，観察範囲よりも下流側で は $9 \mathrm{kV}$ で紡糸をした時が最も粘度上昇が速く, 変形が早 

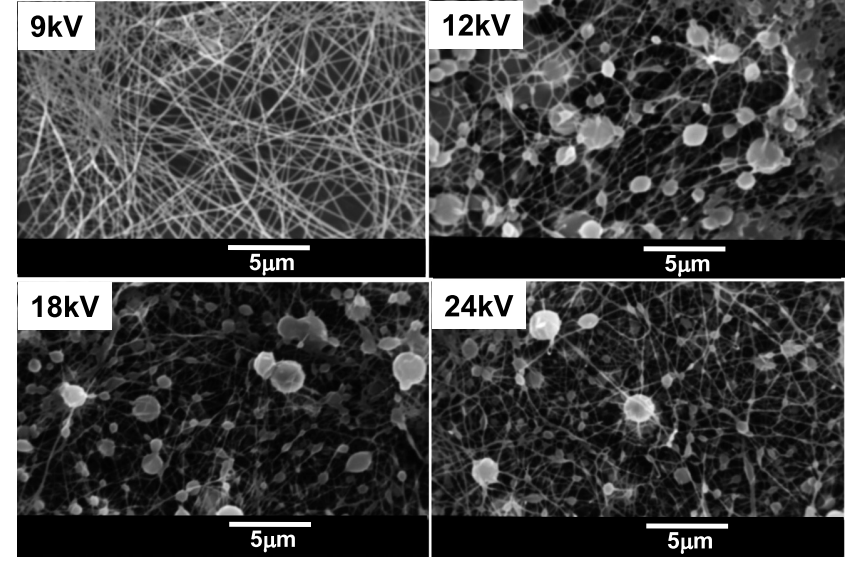

Fig. 6 SEM images of electrospun PVA fibers at different voltages, $9 \mathrm{kV}, 12 \mathrm{kV}, 18 \mathrm{kV}$ and $24 \mathrm{kV}$.

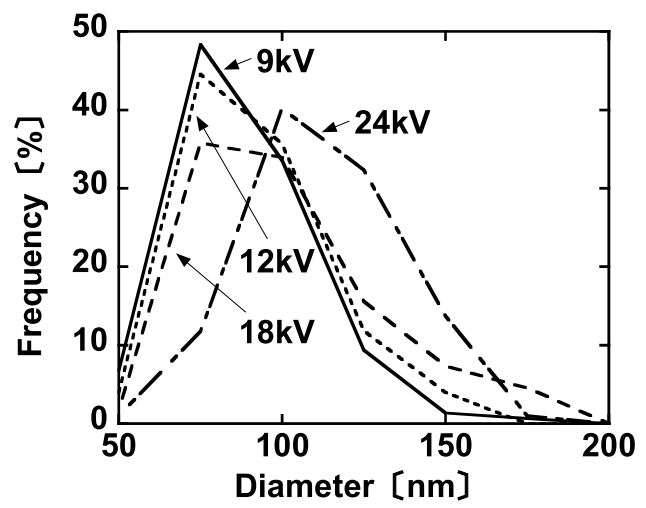

Fig. 7 Fiber diameter distributions at different voltages, $9 \mathrm{kV}, 12 \mathrm{kV}, 18 \mathrm{kV}$ and $24 \mathrm{kV}$.

い段階で安定すると考えられる。ビーズの発生はレーリー 不安定性によって起こることが報告 ${ }^{21}$ されており，レー リー不安定性は高粘度や長緩和時間によって抑制できるこ と ${ }^{22}$ が分かっている。つまり，9kVで紡系を行った場合 は揮発による粘度上昇が速いため，レーリー不安定性を抑 制でき，均一な緎維が作製できたと考えている。逆に，12 $\mathrm{kV}$ 以上の電圧で紡糸を行った際には揮発による粘度上昇 があまり起こらず，レーリー不安定性が成長してビーズに なったと考えられる。本実験で観察可能な範囲では，溶媒 の揮発がまだほとんど起きていないので，今後は揮発の影 響がはっきり分かるような，さらに広い観察範囲で現象の 変化を追っていきたいと考えている.

\section{2 相対湿度の影響}

湿度を変化させた場合の直径分布を図 8 に示す．どの条 件でも電圧を変化させた場合のような顕著な違いは見られ ず，ほとんど同じ変形をしていることが分かった．得られ た直径分布から算出した速度分布を図 9 に示す。直径分布 に大きな差がなかったため, 速度分布もほとんど差がな かった．前節と同様な方法を用い速度分布から算出した揮 発速度分布を図 10 に示す．湿度が $20 \% ， 30 \%$ の時は湿度 が低いため揮発速度変化も速いことが分かる．揮発速度変 化の傾きは湿度の上昇とともに徐々に緩やかになり揮発速 度が遅くなっていく．これは式(4)の係数である $\left(p_{s}-p\right)$

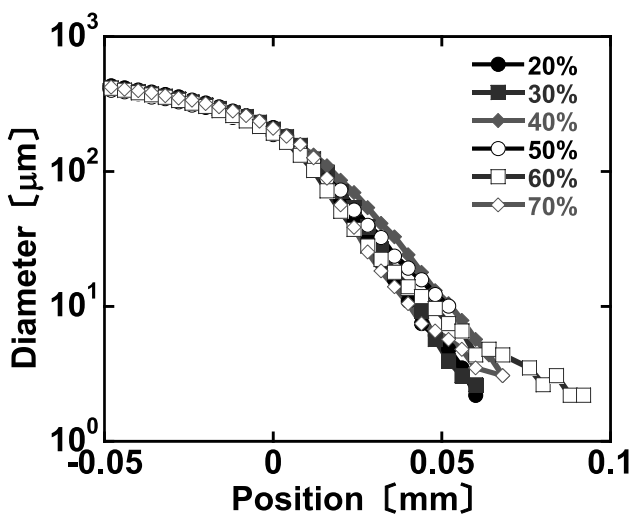

Fig. 8 Jet diameter profiles at different relative humidity, $20 \%, 30 \%, 40 \%, 50 \%, 60 \%$ and $70 \%$.

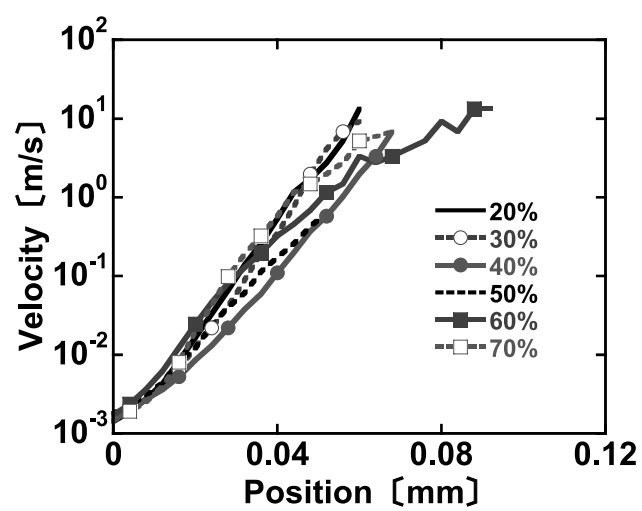

Fig. 9 Jet velocity profiles calculated from jet diameter profiles at different relative humidity, $20 \%, 30 \%, 40 \%, 50 \%, 60 \%$ and $70 \%$.

の值が湿度の上昇につれて小さくなるためである．図 11 に各湿度で紡系を行って得られた繊維構造体の繊維構造を 示す。湿度が $50 \%$ 以下の低いときは均一な繊維が形成さ れるのに対して $60 \%$ 以上の湿度では量は少ないがビーズ 構造が確認された。また，このときの纎維径分布を図 12 に示す．湿度が高くなるにつれて繊維径が小さくなってい ることが分かる。これらのことから，初期にほぼ同じ変形 を受けていても，湿度が異なることにより揮発速度が変化 し, 纎維構造や繊維径に影響を与えていることが分かった. 湿度が低いときには乾燥が速く進むため, 粘度上昇により 形状は安定するが, 伸長変形し難くなるため瀻維径が大き くなる，逆に湿度が高い場合には，揮発し難くなるため粘 度上昇が遅くなり繊維径は小さくなるが, 形状が不安定に なると考えられる。

\section{4. 結言}

本論文では，エレクトロスピニングにおける印加電圧と 相対湿度が変形挙動, 繊維構造に及ぼす影響について調査 した. 印加電圧の影響の調查では, 印加電圧が高くなるに つれて直径変化, 速度変化, 揮発速度変化が緩やかになる ことがわかった，さらに， $9 \mathrm{kV} て ゙$ 紡糸を行った際，均一 で小さい繊維径を持った繊維が確認できた。これは, 直径 変化が速く, 揮発速度変化が速いことに起因すると考えら 


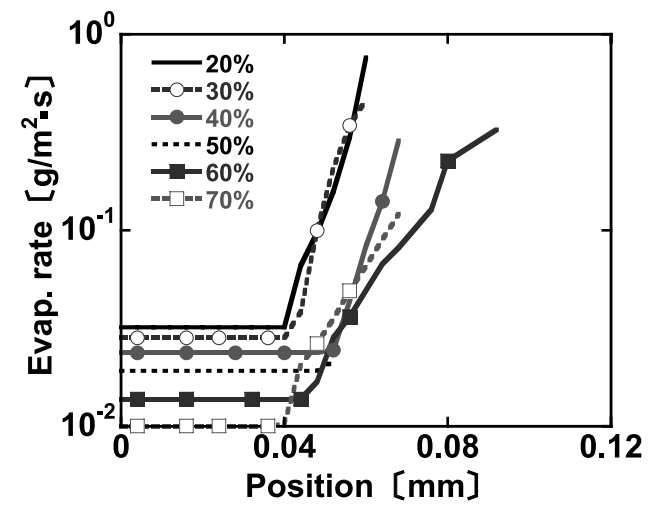

Fig. 10 Evaporation rates calculated from jet velocity as a function of the position $x$ for different relative humidity, $20 \%, 30 \%, 40 \%, 50 \%, 60 \%$ and $70 \%$.

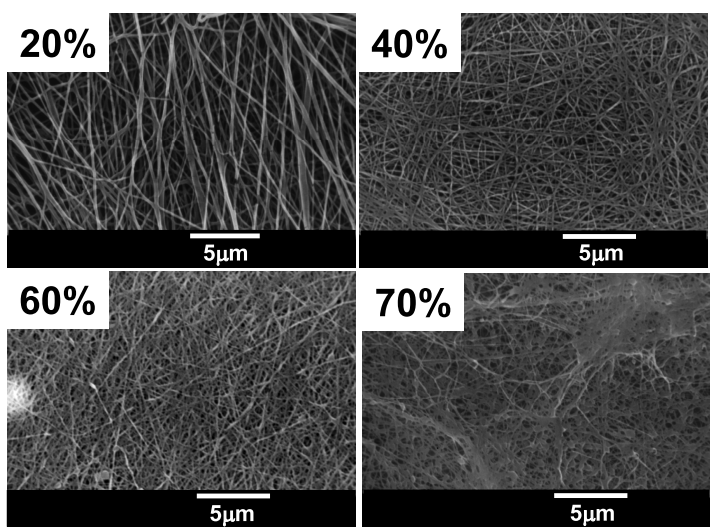

Fig. 11 SEM images of electrospun PVA fibers at different relative humidity, 20\%, 40\%, $60 \%$ and $70 \%$.

れる. 相対湿度の影響では, 相対湿度を変化させても直径 分布, 速度分布はほとんど変化なく, 同じ変形を受けてい ると考えられる。一方, 揮発速度についてみてみると, 相 対湿度が低いほど試料表面と紡系雲囲気の蒸気圧差が大き くなるため, 揮発速度の変化は大きくなり, 湿度が高くな るにつれてその変化は緩やかなものになった．このときの 繊維構造を確認すると, 湿度が低いほど䋊維径は大きく, 均一な繊維構造ができ, 湿度が高くなるにつれて, 䋊維径 が小さく，ビーズ構造を持つことが確認できた.

\section{謝辞}

本研究は科研費, 特定領域研究「非平衡ソフトマター物 理学の創成：メソスコピック系の構造とダイナミクス」の 援助を受けています.

\section{参 考 文 献}

1) Huang, Z. M., Zhang, Y. Z., Kotaki, M. and Ramakrishna, S. : Compos. Sci. Tech., 63, 2223 (2003)

2 ) Dersch, R., Steinhart, M., Boudriot, U., Greiner, A. and Wendorff, J. H.: Polym. Adv. Technol., 16, 276 (2005)

3 ) Casper, C. L., Stephens, J. S., Tassi, N. G., Chase. D. B.

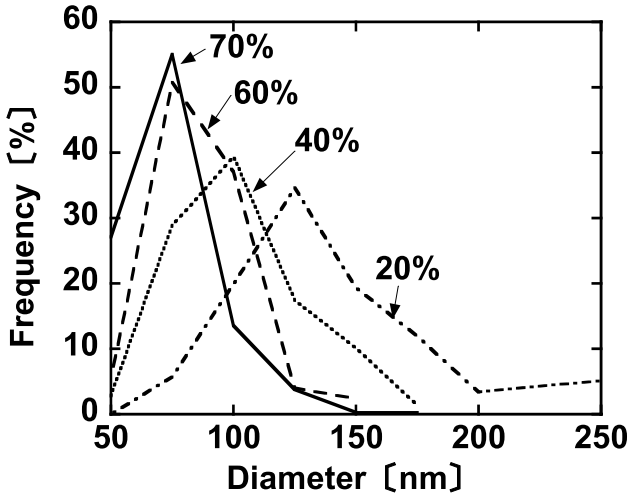

Fig. 12 Fiber diameter distributions at different relative humidity, $20 \%, 30 \%, 40 \%, 50 \%$, $60 \%$ and $70 \%$.

and Rabolt, J. F. : Macromolecules, 37, 573(2004)

4 ) Koski, A., Yim, K. and Shivkumar, S. : Mater. Lett., 58, 493(2004)

5 ) Jun, Z., Hou, H. Q., Wendorff, J. H. and Greiner, A. : $E$ Polymers, Art. No. 038(2005)

6 ) Baumgarten, P. K. : J. Colloid Interf. Sci., 36, 71 (1971)

7 ) Fong, H., Chun, I. and Reneker, D. H. : Polymer, 40, 4585 (1999)

8 ) McKee, M. G., Wilkes, G. L., Colby, R. H. and Long, T. E. : Macromolecules, 37, 1760 (2004)

9 ) Zeng, J., Xu, X. Y., Chen, X. S., Liang, Q. Z., Bian, X. C., Yang, L. X. and Jing, X. B. : J. Control. Release, 92, 227 (2003)

10) Zong, X. H., Kim, K., Fang, D. F., Ran, S. F., Hsiao, B. S. and Chu, B. : Polymer, 43, 4403 (2002)

11) Yang, Y., Jia, Z. D., Li, Q. and Guan, Z. C. : IEEE Transaction on Dielectrics and Electrical Insulation, 13, 580 (2006)

12) Deitzel, J. M., Kleinmeyer, J., Harris, D. and Tan, N. C. B. : Polymer, 42, 261 (2001)

13) Demir, M.M., Yilgor, E. and Erman, B.: Polymer, 43, 3303 (2002)

14) Mo, X. M., Xu, C. Y., Kotaki, M. and Ramakrishna, S. : Biomaterials, 25, 1883 (2004)

15) Ma, M., Mao, Y., Guputa, M., Gleason, K. K. and Rutledge, G. C. : Macromolecules, 38, 9742 (2005)

16) Kadomae, Y., Amagasa, M., Sugimoto, M., Taniguchi, T. and Koyama, K., : Int. Polym. Proc., 23, 377 (2008)

17) Helgeson, M. E., Grammatikos, K. N., Deitzel, J. M. and Wagner, N. J.: Polymer, 49, 2924 (2008)

18）上田政文：湿度と蒸発， $137(2000)$, コロナ社

19) Zhang, C., Yuan, X., Wu, L., Han, Y. and Sheng, J.: European Polymer Journal, 41, 423 (2005)

20) Ki, C. S., Baek, D. H., Gang, K. D., Lee, K. H., Um, I. C. and Park, Y. H. : Polymer, 46, 5094 (2005)

21) Zuo, W., Zhu, M., Yang, W., Yu, H., Chen, Y. and Zhang, Y.: Polym. Eng. Sci., 45, 704 (2005)

22) Bousfield, D. W., Keunings, R., Marrucci, G. and Denn, M. M. : J. Non-Newtonian Fluid Mech., 21, 79 (1986) 